\title{
Participation of Women in Rural Saving and Credit Cooperatives and Its Effects on Household Saving: The Case of Kedida Gamela Woreda, Southern Ethiopia
}

\author{
Eyob Mekuria (Msc) ${ }^{1} \quad$ Zebenay Shitaye (Msc) $^{2} \quad$ Teshome sirany (Msc) $^{3} \quad$ Tseganesh K. (Msc) $^{4}$ \\ 1.College of Agriculture and Natural resource, department of rural development and agricultural extension \\ 2.Debre Markos University, p. o box 269, Debre Markos, Ethiopia \\ 3.College of Agriculture, School of development, environment and gender studies \\ 4.Hawassa University, P. o. box 05, Hawassa, Ethiopia
}

\begin{abstract}
Women participation in rural saving and credit cooperatives is one of the means to get credit/loan to start income generating activities and to improve the living standard of the household as well as their savings in kedida Gamela woreda southern Ethiopia. The study used cross- sectional survey design. Multi-stage sample selection method was employed. In the first stage, the woreda was selected purposely. In the second stage, RUSACCOs were selected through simple random sampling procedure. In the third stage.193 respondents were selected from stratified participant and non-participant women from sampled kebele RUSACCOs using systematic random sampling technique. Primary data were collected through structured interviews, key informants and focus group discussion. The data were analyzed with the SPSS (version 20). Descriptive statistics and inferential statistics such as frequency, percentage, t-test, chi-square test, logistic regression and multiple linear regression models were used for data analysis. The results showed that $68.8 \%$ sampled women had increased their household saving and income but $32.2 \%$ showed no change in their household saving. Logistic regression model result revealed that women participation in RUSACCO was significantly affected by access to loan, level of education and participation in extension. On the other hand multiple regression models results revealed that household saving was significantly affected by educational level of respondents, access to loan, interest rate and participation in extension. This study recommends that the RUSACCOs, government and different NGOs should work closely for improving household saving and income.
\end{abstract}

Keywords: Women participation in RUSACCO and its effects on household saving.

DOI: $10.7176 / \mathrm{DCS} / 9-12-04$

Publication date: December $31^{\text {st }} 2019$

\section{INTRODUCTION}

\subsection{Background of the Study}

Microfinance institutions increase opportunities for poor section of every society by helping them to access credit and introducing the habit of saving. The major reasons formal financial institutions financially exclude the poor is associated with high risks and high costs. There is enormous amount of uncertainty with regard to the repayment capacity of the poor. Information regard to credit is inadequate or unavailable, expenditure and income patterns of the poor are irregular, and the majority of the poor do not have collateral. In addition to this high probability of exposure to systematic risks including crop failure or commodity price fluctuation is fairly high, thus lending to the poor is a high risk investment with high probabilities of default (Solomon et al, 2016).

Banks are often reluctant to offer rural banking services to the poor because of existing information asymmetries. Adverse selection and moral hazard are two typical causes of information asymmetries. The lender has little or no information on the quality of its borrowers i.e. whether they are risky or are they safe (Chowdhury, 2010).

In addition, banks exclude the poor due to high transaction cost of serving the rural poor. Small loan size requirement but frequent loan transaction is another reason of the exclusion. In sum these are seen as the main issues that led to the failure of rural credit markets and to continued exclusion of the poor from those markets in most developing countries (Morduch, 1999).

The provision of financial resources to the poor is widely believed to increase their incomes and productivity. This strategy follows from the assumption that economically active poor people fail to access financial resources from the traditional financial institutions. MFIs are the suppliers of financial resources to the poor. About 90 percent of people in developing countries lack access to financial resources from formal financial institutions like banks (Stephen et al, 2013).

Microfinance emerged as a remedy to these issues with the objective to resolve them by employing range of financial innovations. The principle of group lending lies at the center of those innovations. According to this approach, members of the groups are mutually responsible for repaying the loans which leads to self-monitoring within the group and make each member to work hard to be more successful. 
The government of Ethiopia supports microfinance institutions as one of the means addressing the poorest segment of the society to reduce poverty. To this end, the government created conducive environment for the development of microfinance institutions by issuing proclamation No.40/1996 (the microfinance law). Rural Credit and Saving Cooperatives (RUSACCOs) are one of the largest microfinance institutions operating in Ethiopia established in accordance with the above mentioned proclamation.

It was registered as Share Company on November 25, 1997 and started operation in the second half of the 1998. It is an active member of Association of Ethiopian Microfinance Institutions (AEMFI). Its microfinance market is the low income population of the woreda, particularly of the Kedida Gamela woreda. Rural saving and Credit Cooperatives primary mission is to improve the economic situation of low income, productive poor people in Kedida Gamela woreda primarily through increased access to lending and saving services.

The main activities performed by RUSACCOs are carryout micro financing activities both in urban and rural Ethiopia, particularly, credit, promoting saving, money transfer and pension fund management, mobilize resources from various sources, promotional counseling and training services and plough back profits generated from operations.

The study aims to assess the effects of women participation in RUSACCO on household saving by taking a case study of Kedida Gamela Woreda three primaries RUSACCOs Southern Ethiopia Kembata Tembaro Zone. It was conducted by assessing the clients (treatment group) who are participating in the program and non-participants (control group).

\subsection{Statement of the Problem}

Domestic resource mobilization is a key determinant to support rapid economic growth and development. Realizing sustainable economic growth in a country requires huge amount of savings and investment. However, in most developing countries including Ethiopia, huge saving investment gap is a serious problem which creates difficulty to finance investments needed for growth from domestic savings. Due to this, financing investment through domestic government borrowing and/or foreign loan and grants has been taken as a short run solution by developing countries (Solomon et al, 2016).).But this is not a reliable long run solution rather it would significantly increase the countries debt burden in the future.

In the process of economic development, women's participation is less than that of men in different economic aspects of household, community as well as the country. It would not be out of place to accept the socio economic standard of women as an indicator of development of the country because women constitute almost half of the population of Ethiopia. It is evident that only an active involvement of the women a huge labor force consisting of $50.2 \%$ of the total population in every aspects can accelerate the pace of development by increasing production (CSA, 2018).

Microfinance institutions increase opportunities for poor section of every society by helping them to access credit and introducing the habit of saving. And the emergence of these institutions has been seen as a solution for low domestic savings through accessing the rural poor households in financial services. Webster and Fidler (1999) viewed access of financial services to the poor as a tool to escape from poverty through investing in income generating activities and introducing the habit of saving in rural poor households. If rural poor households have access to financial services, they have the capacity and the desire to save and would respond appropriately to saving opportunities and incentives. Among the proponents of this view, Coleman and Williams (2006) argued that the poor do save even though they do not have complete access to savings facilities in formal financial institutions. Instead, the poor use informal channels and non-financial assets for their savings which are not visible to formal financial institutions. If they get access to financial services, they become active and regular savers.

Therefore, the gap identified from most literatures is that the participation of women in RUSSACOs and its effect on household saving is not specifically studied from the context of Kedida Gamela woreda imitates to conduct the research.

\subsection{Objectives of the Study}

\subsubsection{General Objective}

$>$ The general objective of the study is to assess participation of women in saving and credit cooperatives and its effects on household saving in Kedida Gamela woreda.

\subsubsection{Specific Objectives}

$>$ Assess level of women participation in RUSACCOs

$>$ Analyze the factors affecting women participation in rural saving and credit cooperatives;

$>$ Identify the effect of women's participation in rural saving and credit cooperatives on household saving

\subsection{Research Questions}

$>$ What is the level of women participation in RUSACCOs?

$>$ What are the factors affecting women participation in RUSACCOs? 
What the effect of women's participation in rural saving and credit cooperatives on household saving?

\subsection{Significance of the Study}

The Study is vital because it provides information that will fill identified knowledge gap so as to design more effective and efficient strategies with regard to women participation in RUSACCOs and its effects on household saving. It provides also an opportunity to understand the local knowledge, skill and experiences which will help to further improve the existing effect of women participation in RUSACCOs on their household saving.

Furthermore, it will enable development practitioners, development actors and policy makers to implement effective strategies and policies to encourage the practice of women participation in rural saving and credit cooperatives in the study area.

\subsection{Scope of the Study}

The study was focused on the participation of women in RUSACCOs, factors affecting women's participation in RUSACCOs and its effect on household saving, and factors influencing household saving of the women members. Specifically, the study deals with a limited number of households and focuses on the factors affecting women participation in RUSACCOs, effect of women participation in RUSACCOs on their household saving.

And the study was limited to only three (3) RUSACCOs out of twenty nine (29) RUSACCOs of Kedida Gamela Wereda. The three RUSACCOs were selected due to their accessibility, the familiarity of the researcher with the study area; availability of required information and their differences in distances one from the other.

\subsection{Limitation of the Study}

Even if this study has numerous advantages, it has its own limitations. This study was limited in scope due to limited resources in terms of budget and time. Moreover, one of the limitations of the study lies on its research design. The study used cross-sectional survey design which gathered data at one period. As a result, the study cannot show the full effects of RUSACCOs on household saving because effects of participation in RUSACCOs can be identified either by collecting data repeatedly over time or conducting controlled experimental study.

\section{RESEARCH METHODOLOGY}

\subsection{Description of the Study Area}

Kedida Gamela woreda is found in Kembata Tembaro Zone of Southern Nations Nationalities and Peoples Region (SNNPR). It is located at about $350 \mathrm{kms}$ South West of Addis Ababa, and $125 \mathrm{kms}$ from the regional (SNNPRS) city Hawassa whereas the absolute location of the study area is $7^{0} 11^{\prime} \mathrm{N}$ to $7^{0} 19^{\prime} \mathrm{N}$ and $37^{0} 50^{\prime} 30^{\prime \prime} \mathrm{E}$ to $38^{0} 4^{\prime} 30^{\prime \prime} \mathrm{E}$ (WANRDO,2012).Kedida Gamela Woreda has 18 Rural Kebeles and 1 urban administration (KGWOFED, 2017). The total population of Kedida Gamela Woreda is estimated to be 101,290(male 50077, and female 51,213(WOFED, 2018). According to the Woreda agricultural office information source, the total number of households in the woreda is estimated to be 40,773 households (male headed households 25,750, female headed households 15,023) with an average family size of 4.96 persons per house. Kedida Gamela woreda extension users' male headed 12,210and female headed extension users are 2344 and the total of 14,554(WOFED, 2015).

\subsection{Research Design}

The research design that was used in this study is cross-sectional survey. It is frequently used in socio-economic studies. It uses data from a sample that will be used to make interferences about a population i.e. it is also used to establish whether relationships or associations exist among specific variables that allow making predictions (about the population).

\subsection{Sampling methods and technique}

To select the sample for this study, multi-stage sampling method was employed. In the first stage, the study area (Kedida Gamela) was purposively selected due to access of the area, Kedida Gamela Woreda, In the second stage, it was identified that Kedida Gamela Woreda has a total of twenty nine (29) primary RUSACCOs which have been recognized by the government (KGWCPO, 2018). Out of those RUSACCOs three sample RUSACCOs were selected by simple random sampling method. In the third stage, from three selected kebeles as well as RUSACCOs the women were stratified into RUSACCO participants and nonparticipant groups. Then systematic random sampling technique was employed to select sample units from each participant and non-participant groups to the structured interview.

Accordingly, sample size was determined based on the recommended formula as listed below:

$\mathrm{n}=\mathrm{N} / 1+\mathrm{N}(\mathrm{e})^{2}$

$3752 / 1+3752(0.07)^{2}=193$, Where: $n=$ Sample size, $N=$ Total population, $\boldsymbol{e}=$ Sampling Error

Therefore, 193respondents were selected from stratified participant and non-participant women from sampled RUSACCOs by using systematic random sampling technique as shown in Table 2. 
Table 1: Sample kebeles, RUSACCOs, participants and non-participants and their proportional sample size computation as well as the number of sampled respondents

\begin{tabular}{|c|c|c|c|c|c|}
\hline $\mathrm{S} / \mathrm{N}$ & $\begin{array}{l}\text { Name of the } \\
\text { kebele }\end{array}$ & $\begin{array}{l}\text { Name of } \\
\text { cooperative }\end{array}$ & $\begin{array}{l}\text { Participants of } \\
\text { RUSACCO }\end{array}$ & $\begin{array}{l}\text { Non participants } \\
\text { Any MFIs }\end{array}$ & $\begin{array}{l}\text { Sample RUSACCO } \\
\text { (Participants+Non } \\
\text { participants) }\end{array}$ \\
\hline 1 & DegaKedida & Haro/Gamela & 254 & 1490 & $13+77=90$ \\
\hline 2 & Kerchicho & Adama/Zeraro & 196 & 822 & $10+42=52$ \\
\hline \multirow[t]{2}{*}{3} & Zatoshodera & Zato/Shodera & 98 & 892 & $5+46=51$ \\
\hline & & Total & 548 & 3204 & $28+165=193$ \\
\hline
\end{tabular}

Source: Computed by using data obtained from Woreda cooperative Office, 2018

\subsection{Sources of Data}

Primary information was collected by using interview, questionnaires, observation and focus group discussion. Secondary data were obtained from documentary sources such as books, research papers, manual files, magazine, pamphlets, newsletters and brochures with data related to the topic to supplement and to make comparison with the information which were obtained by using other methods.

\subsection{Method of Data Collection Procedures}

To ensure validity and reliability of the instruments, different data collection techniques such as structured interview, key informant interview, focus group discussion and review of RUSACCO related document in woreda were employed.

\subsection{Methods of data analysis}

Prior to data analysis, the collected data were sorted out, edited, coded, organized, and summarized. Data were analyzed using descriptive and inferential statistics. The statistical package for social science, SPSS (version 22) software, was adopted for data analysis. Specifically, descriptive statistics such as percentage, frequency and mean were employed during analysis and interpretation of women participation in RUSACCO and its effects on household saving. As inferential statistics, (independent T-test, chi-square, logistic and multiple linear regression model) were used to identify the associations between dependent variables and the independent variables while taking the research objective into consideration.

Table 2 Variables used in regression models

\begin{tabular}{ll}
\hline $\begin{array}{l}\text { Dependent variable: Women participation in } \\
\text { RUSACCO(dummy) }\end{array}$ & Dependent variable: Household saving ( in birr) \\
\hline $\begin{array}{l}\text { Independent variables and hypothesized sign } \\
\text { Age(-) }\end{array}$ & Independent variables and hypothesized sign \\
Household size $(+,-)$ & Household size $(+,-)$ \\
Education $(+)$ & Education $(+)$ \\
Marital status $(+,-)$ & Marital status $(+,-)$ \\
Occupation $(+,-)$ & Occupation $(+,-)$ \\
Access to training $(+)$ & Access to training $(+)$ \\
Participation in Extension $(+)$ & Participation in Extension $(+)$ \\
& Access to loan $(+)$ \\
& Experience in different IGAs $(+)$ \\
& Annual income $(+)$ \\
\hline
\end{tabular}

Source: Own survey, 2018

\subsection{Ethical consideration}

As governed by the ethical rights, the researcher informed the participants about the aim of the study and they participated based on their own willingness. Accordingly, privacy and confidentiality were maintained. Procedure were followed as per (according to) work plan and schedule. Before the data collection, the researcher secured oral consent from the respondents.

\section{RESULTS AND DISCUSSION}

\subsection{General characteristics of Respondents}

The mean (standard deviation) value of ages in participants was 36.93(6.721) whereas the mean (standard deviation) values of non participants was 42.35(7.306). The mean household size of respondents and standard deviation of sampled women is 5.23 and 1.862 at the same time the minimum and maximum household is 1 and 10, respectively. The findings from Table 4 shows that, 134 (69.4\%) of the women respondents were married whereas the rest 59 
$(30.6 \%)$ of the respondents were single (widowed \& divorced).

The findings in Table 4 revealed that, the mean educational level of respondents varies with their participation status in microfinance (RUSACCO) activities.

Respondent women relationship with means of livelihood is one of the socioeconomic factors which determine their status of participation in RUSACCOs. As the result indicated in the table below most of the respondents 141(73.1\%) depend on non-farming activities for their livelihood.

Table 3 Socio-demographic characteristics of women (continuous variables)

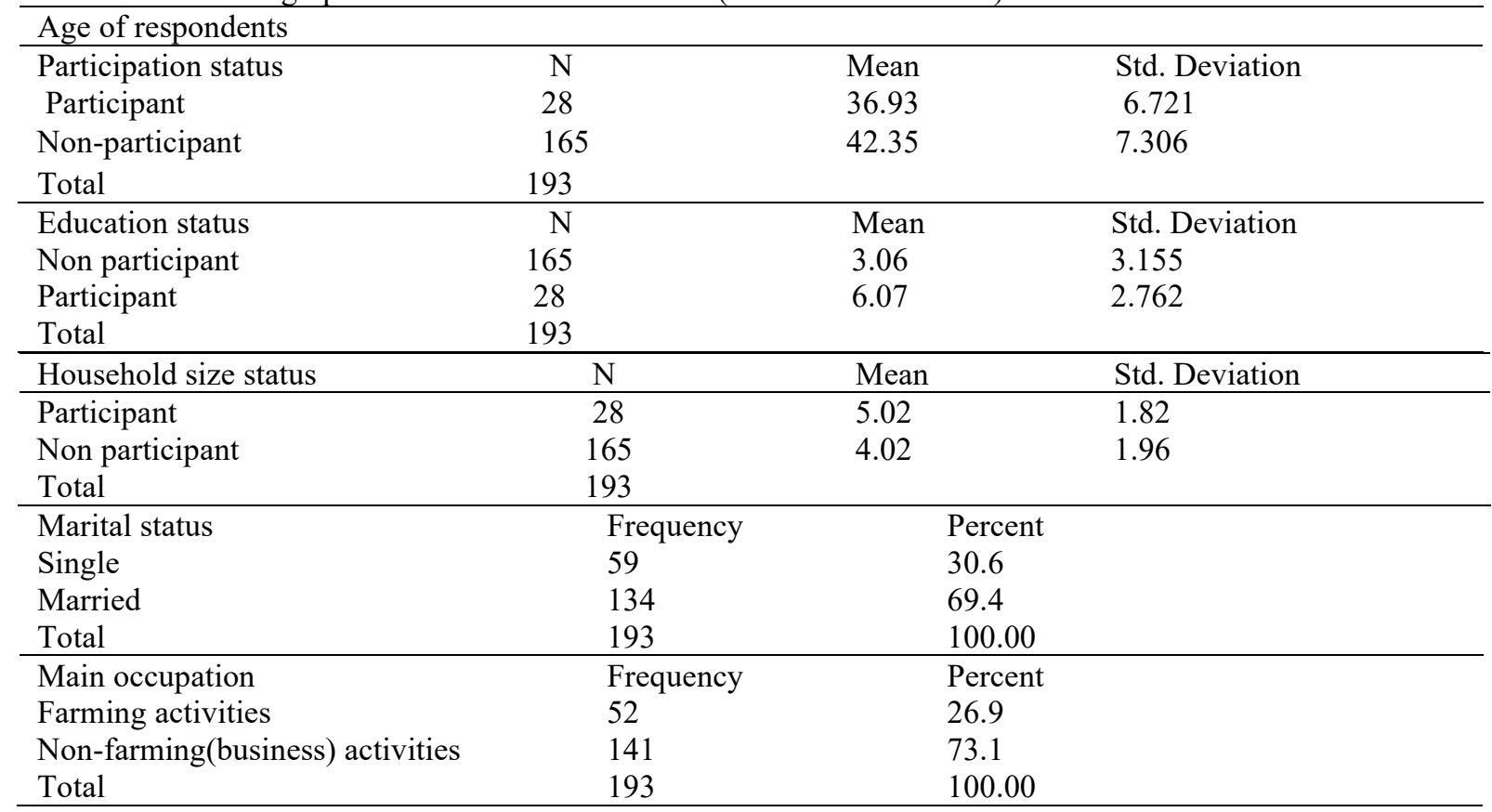

Source: Own computation, 2018

\subsection{Assessing the Level of women participation in rural saving and credit cooperatives}

\subsubsection{Participation of women in general assembly and other committees}

General assembly is the total member of the society and is the supreme organ of the society. In this study, it was trying to assess the level of women participation at different supreme organ of the cooperative society. As indicated in Table 5, the level of women participation in general assembly was below (50\%). Only (17.9\%) of the respondents were attending the general assembly frequently. In management and credit committees, the participation of the women respondents was extremely low. The data indicated very encouraging and half $(50 \%)$ of the committees were women even though the result is dominated by HaroGamela SACCO. FGD indicated that, even though there were more numbers of women in Credit committees, there were not active participants. Their level of participation in the committees were very limited due to different factors such workload in and around the homestead.

Table 4 Participation of women in RUSACCO

\begin{tabular}{lll}
\hline Attending in general assembly meeting & Frequency & Percent \\
Lower & 10 & 35.7 \\
Moderate & 13 & 46.4 \\
Very high & 5 & 17.9 \\
Total & 28 & 100 \\
\hline Attending management committee & & \\
Lower & 15 & 57.1 \\
Moderate & 10 & 35.7 \\
Very high & 3 & 7.2 \\
Total & 28 & 100 \\
\hline Attending credit committee & & \\
Lower & 14 & 50.0 \\
Moderate & 10 & 35.7 \\
Very high & 4 & 14.3 \\
Total & 28 & 100 \\
\hline
\end{tabular}

Source: Own Field Study Result, 2018. 


\subsubsection{Participation of women in training}

Based on Table 6, 42.8\% of the members of the RUSACCOs have got different types of training before joining while $57.2 \%$ were not. But, after joining RUSACCOs about $60.7 \%$ have got training and still $39.3 \%$ were not. It is possible to conclude that, even though there was more progress in giving training for members, but still $39.3 \%$ $(\mathrm{n}=16)$ of the participants were no undergoing SACCOs related training and this have influence on the participations of the women in the cooperative activities.

Table 5 participation access to training

\begin{tabular}{lllll}
\hline Access to training & Before joining RUSACCO & \multicolumn{2}{c}{ After joining RUSACCO } \\
& Frequency & Percent & Frequency & Percent \\
\hline Yes & 12 & 42.8 & 17 & 60.7 \\
No & 16 & 57.2 & 11 & 39.3 \\
Total & 28 & 100 & 28 & 100 \\
\hline
\end{tabular}

Source: Own Field Study Result, 2018.

\subsubsection{Participation of women in leadership}

As indicated in table (7) $78.6 \%$ of the respondents were simple (first) participants and $14.3 \%$ of them also engaged in different sub-committees especially part of the education and social services of the cooperatives. Only $7.1 \%$ of the respondents participated at higher level of the decision making or management body. This indicated that, most of the women were not elected in management committees to lead the cooperative societies. So, women leadership in cooperatives was not given attention by the community or participants of the rural saving and credit cooperatives. Similar studies (ILO, 2002) Access to educational and training facilities, hampers them in taking up leadership roles as they consequently lack the necessary experience, knowledge and skills required.

Table 6Leadership position in RUSACCO

\begin{tabular}{lll}
\hline Position in the RUSACCO & Frequency & Percent \\
\hline Member only & 22 & 78.6 \\
Member of the management committee & 2 & 7.1 \\
Member of sub committee & 4 & 14.3 \\
Total & 28 & 100 \\
\hline
\end{tabular}

Source: Own Field Study Result, 2018.

3.2.4. Participation of women in saving

The finding of respondents' saving behavior is not as expected. As indicated in Table 9, only (32\%) of the respondents have saving deposit at the time interview and (68\%) do not have. The reason is most of the respondent have no information about saving before they join the rural saving and credit cooperatives.

In addition to the above, their saving amount also before and after has big difference. The amount of saving of participants was increased from 500-above 2000 Birr. Therefore as level of participation increases amount of saving increase.

Table 7 participation in saving

\begin{tabular}{|c|c|c|c|c|c|}
\hline \multirow{2}{*}{\multicolumn{2}{|c|}{ Saving }} & \multicolumn{2}{|c|}{ Saving before joining RUSACCO } & \multicolumn{2}{|c|}{ Saving after joining RUSACCO } \\
\hline & & Frequency & Percent & Frequency & Percent \\
\hline Having saving $=$ & Yes & & & 9 & 32 \\
\hline$=$ & No & & & 19 & 68 \\
\hline Less than 500 & & 5 & 27.8 & 3 & 11.5 \\
\hline 500 to 1000 & & 7 & 38.9 & 7 & 26.9 \\
\hline 1000 to 2000 & & 3 & 16.7 & 9 & 34.6 \\
\hline Above 2000 & & 3 & 16.7 & 7 & 26.9 \\
\hline Total & & 18 & 100 & 26 & 100 \\
\hline
\end{tabular}

Source: Own Field Study Result, 2018.

3.2.5. Participation of women in share

Share is the primary depositing capital (saving) for saving and credit cooperatives members (participants). As

Table 10 indicates $78.5 \%$ of them had only one share and only $10.7 \%$ had two.

Table 8participation in share

\begin{tabular}{lll}
\hline Amount of share & Frequency & Percent \\
\hline One & 22 & 78.5 \\
Two & 3 & 10.7 \\
Three & 2 & 7.2 \\
Above three & 1 & 3.6 \\
Total & 28 & 100
\end{tabular}

Source: Own Field Study Result, 2018. 


\subsection{Factors affecting participation of women in RUSACCO}

Participation of women in rural saving and credit cooperatives is expected to be affected by different factors. Among different factors which affect women participation in rural saving and credit cooperatives some of them are included in t-test and chi-square test to analyze whether they affect or not.

Table 9Factors affecting women participation in RUSACCO

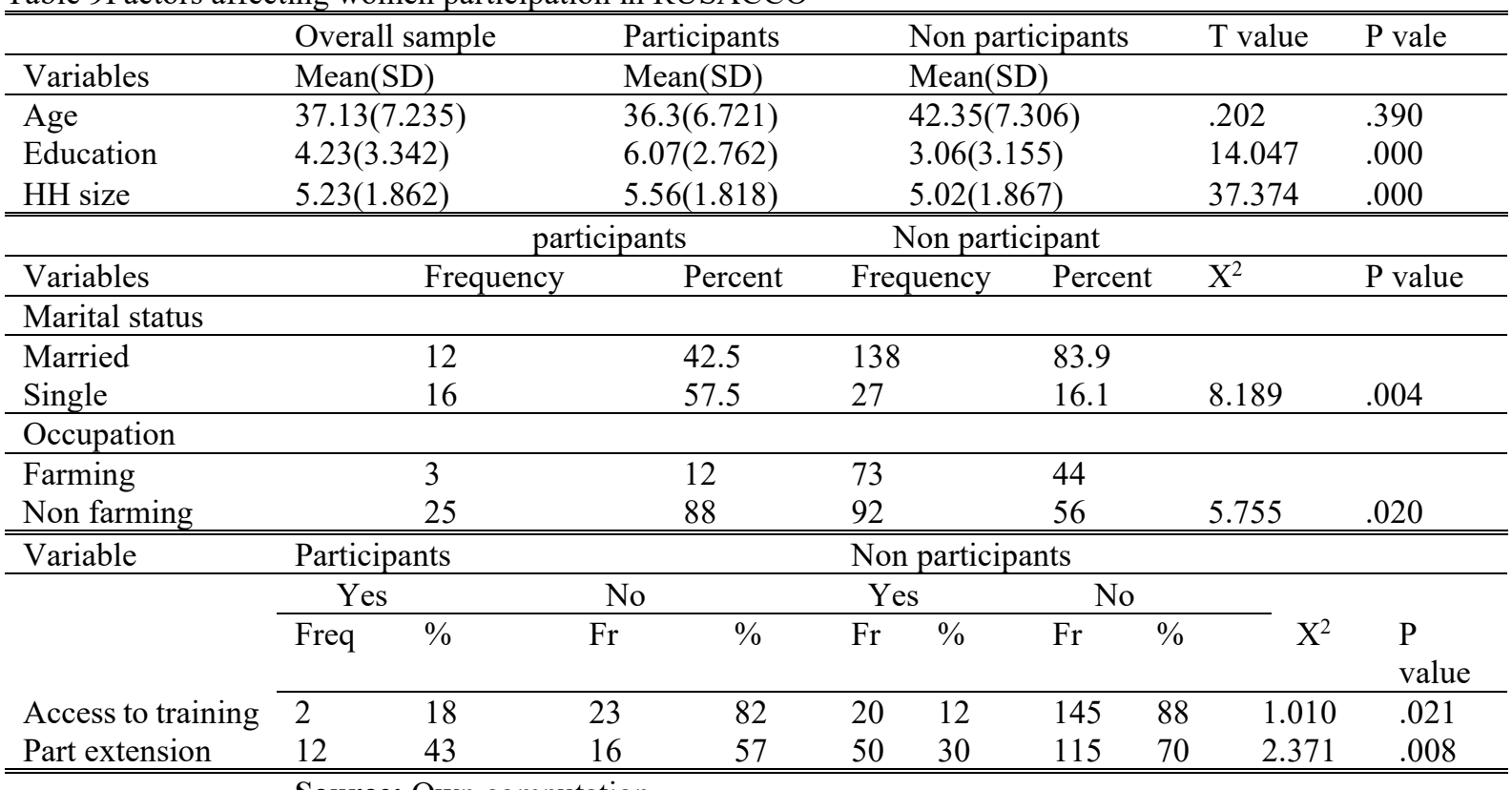

Source: Own computation

In this study, age was used to measure the age of the woman in years. As shown in Table 12, the average and standard deviation of sample respondents age was 37.13(7.235) years, respectively. The average age and standard deviation of participants and non-participants was 36.3(6.721) and 42.35(7.306) respectively. The statistical analysis revealed that as such there is no significant difference in the mean age of the women between participants and non-participants $(\mathrm{t}$ value $=66.831, \mathrm{P}=000)$. The mean educational level of participants and non-participants of sampled respondents was 4.23 and 3.06 , respectively. The statically test confirms that there is a significant difference in the mean educational level of participants and non-participants ( $t$ value=14.047, $p=000)$. The mean household size of respondents and standard deviation of sampled women is5.23 and 1.862 at the same time the minimum and maximum household is 1 and 10 , respectively. Hence the statistical test shows that there is significant difference in mean household size in between participants and non-participants. Therefore household size affects women participation in RUSACCO significantly ( $t$ value $=37.74, p=.000$ ). As it was seen from the chisquare test analysis in the Table 12 above single women are better participants in RUSACCO than married women which are $57.5 \%$ of participants were single women $42.5 \%$ of participants were married women.

Also respondent women relationship with means of production determines their status of participation in RUSACCOs. As indicated in table 12 above $58.5 \%(n=113)$ of sampled women's main occupation was business/non farming activities, and the rest $41.5 \%(n=52)$ respondents occupation was farming activities. From the chi-square test analysis, it is possible to conclude that, the respondents engaged in business /non-farm activities are highly participating in RUSACCO than those who are engaged in farming activities. Therefore the occupation in which women depend to get produce and livelihood affects participation in RUSACCOs significantly $\left(\mathrm{X}_{2}=5.755\right.$, $\mathrm{p}$ value $=.020$ ). Based on that analysis, it is revealed in table 12, respondents who got access to training are hypothesized to participate better than those how have no access to training. From the total of 193 respondents only $22(11.4 \%)$ of women got access to training and the rest majority $143(88.6)$ have no access to training. So as it was seen from the chi-square analysis access to training affects women participation in RUSACCOs. Therefore those who got access to training are more probable to participate in $\operatorname{RUSACCOs}\left(\mathrm{X}^{2}=1.010, \mathrm{p}\right.$ value $\left.=.021\right)$.

Results of the study in Table 12, show that out of the total 193 sampled respondents, $62(32.1 \%)$ of them had contact with extension agents. It could be also inferred from the results that about $67.9 \%$ (103) of total 193 respondents do not have contacts with extension agents. Inability of respondents to devote their time, absence of extension workers nearby and lack of interest in the service are the main reasons mentioned by respondents for not having contact with extension agents $\left(X^{2}=2.371, p\right.$ value $\left.=.008\right)$

\subsection{Result of Econometrics Analysis}

\subsubsection{Determinants of RUSACCOs participation}

Based on final binary logistic regression analysis and as indicated in the table 13, the four variables which affects 
participation of women in RUSACCO were age ,education, household size and access to training.

Table 10Parameter estimates for Log it (variables in the equation)

\begin{tabular}{lllll}
\hline variables & B & S.E. & Wald & Sig \\
\hline Age & -0.058 & 0.027 & 4.781 & 0.029 \\
Education & 0.237 & 0.063 & 14.216 & 0.000 \\
Household size & 0.197 & 0.990 & 3.946 & 0.047 \\
Marital status & 0.555 & 0.412 & 1.814 & 0.178 \\
Occupation & 0.591 & 0.438 & 1.821 & 0.177 \\
Access to training- & -0.844 & 0.383 & 4.856 & 0.028 \\
Participation in extension & 0.447 & 0.387 & 1.333 & 0.248 \\
Constant & -1.629 & 1.881 & .750 & 0.387 \\
\hline
\end{tabular}

Source: Own Field Study Result, 2018

The result of binary logistic regression analysis shows that, at 5\% level of significance, age, education, household size and access to training were significant factors towards women participation in rural saving and cooperatives.

\subsubsection{Determinants of household saving}

Based on final multiple regression analysis and as indicated in the table 14, the four variables which determine the amount of household saving were marital status, household size, access to loan and experience in income generating activities of the women .

Table 11 Parameter estimates for factors affecting saving in multiple linear regression models

\begin{tabular}{lllll}
\hline \hline Category & Beta & Std error & $\mathrm{t}$ & Sig \\
\hline Age & -711.371 & 415.848 & -1.711 & 0.089 \\
Household size & 1451.363 & 384.813 & 3.77 & 0.000 \\
Educational level & 229.978 & 371.481 & .619 & 0.537 \\
Marital status & -954.391 & 409.197 & -2.332 & 0.021 \\
Participation in extension & -232.662 & 364.567 & -.638 & 0.524 \\
Main occupation & 76.832 & 381.374 & -.201 & 0.841 \\
Participation in RUSACCO & 23.194 & 960.754 & .024 & 0.981 \\
Access to loan & 1154.226 & 407.951 & 2.829 & 0.005 \\
Access to training & 341.698 & 498.361 & .686 & 0.494 \\
Experience in IGAs & 1445.898 & 398.637 & -3.627 & 0.000 \\
Interest rate & 2.691 & 0.537 & 5.013 & 0.000 \\
Annual income & -0.003 & 0.020 & -0.153 & 0.878 \\
\hline \hline
\end{tabular}

$\mathrm{R}=0.587 \mathrm{a}$, R square $=0.334$, Adjusted R square $=0.301$, Std error $=2261.32421$

$* * *$ Significant at the $0.05(5 \%)$ level (2-tailed), *** significant at the $0.01(1 \%)$ level (two tailed)

Source: Own Field Study Result, 2018.

Interpretation of Model Results

The result in Table 14 revealed that among the 12explanatory variables entered in the model, five variables had significant influence on household saving of respondent women. These are household size, experience in income generating activities, access to loan and marital status of respondent women. Whereas, the rest five variables such as main occupation, access to training, age of respondents, educational level and contact with extension agents were found to be non-significant on affecting women's household saving.

However, the influence of these variables on the household saving was significant in descriptive analysis. The possible reason for non-significant influence of these variables in multiple regression analysis was based on the viewpoint that these non-significant variables may had indirect influence on respondents household saving or their influence may had already been explained by other significant variables in the model.

\section{CONCLUSION AND RECOMMENDATIONS}

Women in Ethiopia encounter several problems that are multifaceted. Cooperatives have been considered as means of empowering resource poor women who have no access to formal financial facilities economically. They promote the provision of saving, loan; training and information services to the members. Women represent about 50 percent of the total population of the country as well as the study areas. Savings and credit cooperatives (RUSACCOs) will become a stronger economic and more influential in political force if more women are actively involved in cooperatives movement.

Through awareness creation, gender sensitization, education and training, the obstacles to women's participation in RUSACCOs can be solved. Involving more women (in leadership, involving in different committees, and attending in general meeting of the RUSACCOs) in savings and credit cooperative societies will broaden the scope of RUSACCOs and improve their social standing. In this study, it was clearly observed that the level of women participation in all RUSACCOs activities is low. In addition to that after joining the RUSACCO 
most of the women $(92 \%)$ were participating in taking loan from RUSACCOs. But still the rest $8 \%$ of participants were not participating in loan/credit taking.

From this data it is possible to conclude that, the sampled saving and credit cooperatives were effective in giving loan to women members/participants but the amount of loan was limited that was 2000 to 6000 birr. The amount of share owned by the women respondents was limited to one to four.

Women through cooperative were able to acquire more assets than before and have an improved well-being. Most of them were able to increase their monthly income, consumption and educational expense and improve savings. Even though, the annual saving is increased after they joined RUSACCOs, but the number of the participants were very much limited. Women that were participants of RUSACCO have better annual household saving than non-participants of RUSACCOs.

The level of participation of women in RUSACCOs was low in different RUSACCO activities such as, attending general assembly, attending management committee, attending credit committee, participation in leadership participation in saving and participation in share.

Women's participations in RUSACCOs were also significantly affected by explanatory variables like educational level of respondents, household size of respondents, marital status and main occupation of respondents. As seen by chi-square analysis.

Finally the amount of household saving of respondent women was significantly influenced by household size, marital status, and experience in different income generating activities access to loan, interest rate and participation in extension at $5 \%$ level of probability. There is a big gap between participants of RUSACCOs and non-participants in terms of the amount of mean annual household saving.

On the basis of the main findings discussed above, some recommendations were drawn with the purpose of improving and sustaining the level of women's participation in women's self-employed saving and credit cooperatives and household saving.

- Through awareness creation, training and education program which are sensitive to women needs, rural saving and credit cooperatives should focus on women's capacities and capabilities, resulting in increased self-confidence and enabling them to participate more fully and actively at different level of cooperatives function.

- Rural saving and credit cooperatives (RUSACCOs) should work hard to maximize the number of participants since the amount of saving of participants was greater/better than that of non-participants of RUSACCOs.

- Rural saving and credit cooperatives (RUSACCOs) should encourage women to participate in different aspects of extension services to improve information on how to improve productivity and production.

- Rural saving and credit Cooperatives should work hard to encourage women to be engaged in different income generating activities to increase household saving

- The cooperative office should train and consult women living with their husbands to live with them without divorce because married women have better mean annual saving than divorced women.

- The rural saving and credit cooperative should also introduce gender related training to their members to minimize the problem of cultural influence.

- The cooperative experts and cooperative management committees should also focus on women youngsters who have higher educational status to enroll to the saving and credit cooperatives.

- For further research, factors influencing women's participation in saving and credit cooperatives society and its effects on household saving should be assessed in a wider area; since this research was conducted in one Woreda only

\section{REFERENCE}

$>$ The Impact of Microfinance on Household Saving: The Case of Amhara Credit and Saving Institution Feres Bet Sub-Branch, Degadamot Woreda

$>$ Solomon Kebede Menza (MSc in Economics) Tsegaw Kebede T. (MSc in Economics)

DEPARTMENT OF ECONOMICS, COLLEGE OF BUSINESS AND ECONOMICS, WOLAITA

$>$ The Impact of Microfinance on Household Saving: The Case of Amhara Credit and Saving Institution Feres Bet Sub-Branch, Degadamot Woreda

$>$ Solomon Kebede Menza (MSc in Economics) Tsegaw Kebede T. (MSc in Economics)

$>$ DEPARTMENT OF ECONOMICS, COLLEGE OF BUSINESS AND ECONOMICS, WOLAITA

$>$ The Impact of Microfinance on Household Saving: The Case of Amhara Credit and Saving Institution Feres Bet Sub-Branch, Degadamot Woreda

$>$ Solomon Kebede Menza (MSc in Economics) Tsegaw Kebede T. (MSc in Economics)

$>$ DEPARTMENT OF ECONOMICS, COLLEGE OF BUSINESS AND ECONOMICS, WOLAITA

$>$ The Impact of Microfinance on Household Saving: The Case of Amhara Credit and Saving Institution Feres Bet Sub-Branch, Degadamot Woreda 
$>$ Chowdhury (2010). Understanding the Grameen miracle, international and organizational Innovation.

$>$ Deaton, A. (1991). Saving and liquidity constraints. Econometrical, 59, 1221-1248.

$>$ FAO, 1991, "Plan of Action for People's Participation in Rural Development", Ed to FAO, 26 conference Rome.

$>$ FAO (1996). Rome Declaration on World Food Security and Food Summit Plan of Action, Rome.

$>$ ILO, International Lab our Office Geneva first published 2002Internet: www.coops-ethiopia,the revival of cooperatives in Ethiopia, 2005.

$>$ Morduch, J. 1999. Does Microfinance Really Help the Poor: New Evidence from Flagship Programs in Bangladesh. Department of Economics and HIID. Harvard University and Hoover Institution, Stanford University.

$>$ Solomon Kebede etal (2016). Impacts of micro finance on household saving: the case of Amhara credit and saving institution Feresbet sub-Branch, Degadamot woreda

$>$ WCPO 2018, Woreda Cooperatives promotion office, report Feb, 2018. 